"Contested confines: political risk and the media in South Africa"

\begin{tabular}{|c|c|c|}
\hline AUTHORS & $\begin{array}{l}\text { Mary-Anne Piasecki } \\
\text { Piet Croucamp }\end{array}$ & \\
\hline ARTICLE INFO & \multicolumn{2}{|c|}{$\begin{array}{l}\text { Mary-Anne Piasecki and Piet Croucamp (2016). Contested confines: political risk } \\
\text { and the media in South Africa. Problems and Perspectives in Management, 14(2- } \\
\text { 1), 143-154. doi:10.21511/ppm.14(2-1).2016.03 }\end{array}$} \\
\hline DOI & \multicolumn{2}{|c|}{ http://dx.doi.org/10.21511/ppm.14(2-1).2016.03 } \\
\hline RELEASED ON & \multicolumn{2}{|l|}{ Monday, 06 June 2016} \\
\hline JOURNAL & \multicolumn{2}{|c|}{ "Problems and Perspectives in Management" } \\
\hline FOUNDER & \multicolumn{2}{|c|}{ LLC "Consulting Publishing Company "Business Perspectives" } \\
\hline & & $\begin{array}{l}\text { ニニ- } \\
\text { ニẼ }\end{array}$ \\
\hline NUMBER OF REFERENCES & NUMBER OF FIGURES & NUMBER OF TABLES \\
\hline
\end{tabular}

(C) The author(s) 2022. This publication is an open access article. 


\title{
Contested confines: political risk and the media in South Africa
}

\begin{abstract}
The South African private news media industry represents a substantial portion of the overall media industry and the most successful in terms of profit acquired. It is critical however to assess the shareholders and private ownership of the news media industry in order to determine the likely success of investment in this industry. However, additional risk factors need to be considered along with the shareholders and ownership; macro factors such as, legislation and economic stability as well as micro factors such as the restructuring of ownership and transparency within the industry. It is also fundamental that the news media industry of South Africa is assessed through the lens of its historical landscape and transformation and its Fourth Estate responsibilities. Through this assessment it is possible to conclude three likely outcomes of investment in the news media industry. These outcomes are based on the measured growth and current stability of the industry and the South African economy. The most concerning risk for investment is the continued economic downturn of the South African economy and its effect on restructuring of media ownership and a declining profit. This can be coupled with the risk of legislative turnover and executive overreach within the news media industry.
\end{abstract}

Keywords: media, political risk, South Africa, ownership.

JEL Classification: L82, G11.

\section{Introduction}

This paper will critically analyze and discuss the landscape of the South African news media industry with specific focus on private ownership and shareholders within it in order to assess risk of investment within the industry. It is imperative to understand three main objectives of which the paper aims to achieve; 1) getting to grips with the theoretical component of the landscape of South Africa's news media industry; 2) compiling a set of risk indicators, both macro and micro, based on the landscape of South Africa's news media industry, with specific focus on their current owners, shareholders and investors; 3) lastly the paper will provide an assessment of these indicators as a forecast for potential Foreign Direct Investment (FDI).

It is fundamental to begin by stating that the media industry in South Africa is made up by a three-tier system; the commercial sector, the community sector and the public broadcaster, which refers to the South African Broadcasting Corporation (SABC) (Moyo \& Chuma, 2010, p. 40). The commercial news sector will be the primary focus of this discussion, among its Fourth Estate objectives, the commercial media industry must be profitable in order to sustain itself. South Africa's commercial media sector is the most successful of the three mainly due to its wide availability of content and given that its primary market are those participating in the mainstream of the economy (Moyo \& Chuma, 2010, p. 40). This paper will focus specifically on the commercial news media industry, considering South Africa's four largest media houses, referred to

(C) Mary-Anne Piasecki, Piet Croucamp, 2016.

Mary-Anne Piasecki, B.A., Department of Politics, University of Johannesburg, South Africa.

Piet Croucamp, Ph.D., Department of Politics, University of Johannesburg, South Africa. as the 'big four' namely Media24 (Naspers), the Independent Media Group (IMG), the Times Media Group (TMG) and Caxton publishers. It will also incorporate the newest media owner, TNA Media Group and the Mail and Guardian (M\&G) an independently owned title.

\section{The landscape of South Africa's news media industry}

Since 1994 South Africa's media industry has undergone major transformation in order to become more democratic and diverse in terms of ownership, content and market share. Pre-1994 the news media was overseen by an authoritarian government who owned and controlled the Afrikaans press. The media industry did not represent an integrated, diverse and democratic market and was a mouthpiece for government. Post-1994 the new, democratically elected African National Congress (ANC) introduced a number of legal measures and independent regulatory bodies to assist in transforming the media along new constitutional ideals (Fourie, 2001, p. 56). A fundamental part of this transition has been in ownership of the various media businesses in the country.

Oosthuizen (2001, p. 132) identifies the theory of a democratic position of ownership as one which provides a diverse market place with a broad range of information disseminating from various sources. It is considered undemocratic if the media industry of a country practices concentration and convergence of media businesses, to the extent that content produced is limited in terms of opinion and variation. Thus the fewer media houses operating, the higher the risk of centralized control of the press becomes. This means that there are also low levels of competition in the market and the ability of independent competitors to be successful is 
increasingly low given that they must compete against larger media houses within the industry who are able to produce more content at lower price than smaller companies; for example the Mail and Guardian's circulation in 2012 was 45692 per week, while the Saturday Star had a circulation of 97257 per week (Daniels, 2012, p. 45).

However Daniels (2012, p. 43) and Angelopulo \& Potgieter $(2013$, p. 3) argue that the South African news media industry is not a concentrated industry and to the contrary actually lacks unity and cohesion. There is no ideological agenda which the industry portrays nor there is a lack of content variation and opinion within the news media industry. Angelopulo and Potgieter (2013, p. 2) state that by use of a Noam Index, an Index specifically designed to measure concentration, it has been assessed that concentration within newspapers is diminishing.

SoN (2013, p. 2) states that there are 359 newspapers in South Africa; 32 weekend publications, 219 free publications, 58 local publications, 28 daily publications and six hybrids. These publications are printed in largely three languages; English, Afrikaans and isiZulu. To show how diverse the news media industry is we can take an example of South Africa's largest media owner, Naspers and the Media24 group. Media24 publishes the Daily Sun which is South Africa's biggest selling daily paper (circulation of 374400 ). It is an English tabloid style publication and targets low wage working class citizens. While Media24 also publish Rapport, an Afrikaans weekly which provides news and information to Afrikaans working class citizens (Daniels, 2012, p. 44).

The ideal position of a democratic ownership in the media industry centres on how competition exists in it. This means that the primary basis of South Africa's news media industry should be one which participates in a free-enterprise economic system (Oosthuizen, 2001, p. 132). This system is believed to be selfregulatory because the market allows for free competition between owners of media houses, thus there is no price-fixing and concentration. However in many instances, as with South Africa's news media industry, the free market system has led to many media houses forming alliances and converging media companies to create larger, more profitable media house. In 2013 Caxton bought out Habari Media, a digital media sales house whose clients include BBC.com, LinkedIn, MTV, 2Go, All4Women and Autotrader (Bdlive, 2013a, Internet).

In the case of the news media industry, freedom of the press is critical for investment to ensure there is no state intervention which hinders the media industry from performing its Fourth Estate responsibilities. According to Reporters without Borders World Press Freedom Index (2015, Internet) South Africa is ranked 39 out of 180 countries for press freedom, increasing its ranking from 42 in 2014. However in 2003 it ranked at 21 and has steadily declined since and only since 2013 its position has improved. These figures indicate instability in press freedom within the country, which are related to political factors and increased pressure for legislation which censors press freedom. However the current status of media freedom is satisfactory according to Reporters without Borders (2015, Internet).

Legislation is also critical for investment as it is a determining factor of stability within a country. South Africa's government promotes and ensures constitutional and legislative protection for those employed in the media industry, and regulatory bodies protect the public in the media industry. Vilakati \& Mavindidze (2014, p. 16) in a report for the Freedom of Expression Institute (FXI) discuss four legislations critical for South Africa's news media industry.

The first being the Constitution of South Africa, the supreme law governing the country, which makes specific reference to freedom of expression (Act 108 of 1996), particularly freedom of the press and other media as well as the freedom to receive and impart information and ideas. The constitution of South Africa is the highest law of the country, from which, all others must follow. Thus it is significant to highlight that press freedom is protected and that it should be the least of investors' concerns when considering FDI in South Africa's news media industry. Having said this, it must be pointed out that three controversial appeals have been made by government to increase state regulation of the media.

The Protection of Information Act (POI), the proposed Media Appeals Tribunal and the National Key points act show eminence of censorship in media content and government appeal to regulate the media industry (Daniels, 2012, p. 51). The POI Act of 1982 is one of around 12 Apartheid-era restrictive laws which independent regulatory bodies are still struggling to amend (Burger, 2007, p. 106). Government began the process to revise the original act to the 2010 Act of the Protection of State Information Bill (POIB). The POIB faced immense criticism from media analysts for using vague terminology to define state-sensitive information which would legally be withheld from the public. The POI coincided with a renewed appeal from government for a Media Appeals Tribunal (MAT) which would regulate the press in the same way independent bodies do (Letsebe, 2012, Internet). 
The MAT was first introduced in 2007 at the ANCs annual conference, held in Polokwane. The MAT was accompanied by an appeal from government to investigate all press regulation in South Africa (Thloloe, 2012, p. 111). The MAT would, if implemented, regulate the professional ethics and selfregulatory bodies overseeing the press (Oosthuizen, 2014, p. 95). If used correctly the MAT would tackle issues of media transformation yet it is largely considered to be problematic with the constitutionality of South Africa and could be used as method of state intervention into the press, increasing corruption and political control over the media (Daniels, 2012, p. 57). The POIB was adopted by Parliament, yet is still to be signed by the president, who requested further amendments (SoN, 2014, p. 22). Any form of state involvement in the media is a deterrence for potential investors because it promotes an authoritarian, nationalist economic system within a country which would create democratic instability.

The National Key Points Act identifies 182 national key points in South Africa, these locations are undisclosed to the public for security purposes. However the act states that these locations may not be reported on or photographed, which is problematic for media workers as they would be unaware whether they were breaking the law if they happened to report on one of these locations (Daniels, 2012, p. 53). The biggest concern for the media is that government may at any point declare a location as a national key point to avoid scrutiny around it. In 2012 government announced that the presidents Nkandla homestead was a national key point which then shielded government from releasing any figures to the public (SoN, 2014, p. 23).

The second legal protection for the media industry is the Competition Act (39 of 2000) which deals with control and ownership in general thus applying to all businesses. The act promotes wider ownership and the representative of a broad, diverse economy in South Africa. The Competition Commission (CC) regulates this act and has the right to investigate and prosecute companies found in violation of this act such as businesses promoting concentration of ownership, fixing prices and purposely dividing markets in the economy (Vilakati \& Mavindidze, 2014, p. 17). The $\mathrm{CC}$ has probed numerous investigations into the media industry, notably the Media24 group who owns the largest sake in the commercial media sector. The outcomes ruled by the $\mathrm{CC}$ can have two effects on FDI; one is positive and enforces a greater opportunity for investment and shareholdings by opening up control in the industry; the other is negative which requires those found in violation to pay hefty fines over R20 million, which is financial loss for investors and owners in the industry (Visser, 2014, Internet).
The third Act to be discussed is the Broad Based Black Economic Empowerment Act (BBBEE) which primarily seeks to rectify the exclusion of marginalized and disadvantaged groups in South Africa. BBBEE codes of good practice of 2007 provide a framework of measurement and give a detailed description of how a business entity scores according to certain factors relating directly to its employment and economic entities (Vilakati \& Mavindidze, 2014, p. 19). The Labor Relations Act (LRA) and Basic Conditions of Employment Act (BCEA). The LRA (Act 12 of 2007) and BCEA (Act 76 of 1887) ensure employers realize fair and equal labor practices in the workplace which seek to protect the rights of the employee, such as, bargaining in the workplace and the right to form part of trade unions and strikes.

The Employment Equity (EE) Act 55 of 1998 regulates the relationship of the employer-employee and the need to diversify employment and equalise the broader society according to income, occupation and employment of previously marginalized groups such as previously disadvantaged persons (Vilakati \& Mavindidze, 2014, p. 21). It is of significant importance to consider the obligations of businesses to comply with these labor acts. Potential investors must be aware that BBBEE and associated labor and employment law are considered by owners in their business strategies including who invests in their entities. The promotion of South Africans participation in the market share is crucial to diversify and equalize the media industry.

South Africa's media industry also has a variety of independent regulatory bodies which oversee its effective operation. The Imprint Act 43 of 1993 and the Independent Broadcasting Authority Act 153 of 1993 require (respectively) the registration of publications and licensing of broadcasters and publications (Burger, 2007, p. 99). These acts set forth the framework for independent regulatory bodies in South Africa, post 1994. These independent bodies include: The Independent Communications Authority of South Africa (ICASA); the Broadcasting Complaints Commission of South Africa (BCCSA), the Press Council and Ombudsman, the Digital Media and Marketing Association (DMMA); and the South African National Editors Forum (SANEF) (Tholoe, 2013 , p. 110). The provision of legal framework promotes a stable investment opportunity and protects the independence of the news media industry. However there are also negatives to consider, in the sense that policy obligates South African ownership and investment in the media industry which must comply with BBBEE standards. Overall there is a strong legal and regulatory protection of the press and South Africa has maintained a stable democracy. 


\section{Overview of ownership and shareholders}

As the primary focus of this paper relies on determining the risk of investment into the news media industry it is fundamental to discuss the overview of the current media ownership and shareholders of the news media industry. This discussion will expand on the current ownership and shareholders of the dominant four media houses, known as South Africa's 'Big Four' and well as the Mail and Guardian $(M \& G)$ and TNA Media.

\subsection{Media24 group owned by Nasionele Perskor} (Naspers) was founded in 1915 and became primarily affiliated as the mouthpiece for the Apartheid government because of its establishment as the first Afrikaans press in the country (Ooshuizen, 2001, p. 142). In 1994 Naspers was listed on the Johannesburg Stock Exchange (JSE) and expanded its media and publishing interests. Today Naspers can no longer be viewed as a predominantly Afrikaans press, its titles range equally between English and Afrikaans. It is also a level 3 BBBEE contributor, scoring $45 \%$ of black ownership and 12 out of 17 points for preferential procurement according to the BBEE code of good practice (SoN, 2014, p. 18). Naspers also has vast ownership in television, internet and printing businesses. It is South Africa's largest and most profitable media house, owning stake in every aspect of the industry and over $65 \%$ of the print news media industry (Oosthuizen, 2001, p. 143).

In 2014 Naspers grew at 26\% annually (Naspers website, 2015, Internet), showing a continued growth of that can be linked to its investments in over 130 countries including China and Russia and likewise many international consortiums have investment in various stakes in Naspers. Naspers also holds the widest reach of all its competitors in South Africa, with media ranging from print (Media24 group), to broadcasting (owners of SA pay TV Multichoice), to online and in telecommunications (Mweb). The Naspers group in 2015 reached a capital of R850 billion, which was largely due to its recent $34 \%$ stake in a Chinese internet company, Tencent (van Zyl, 2015, Internet).

The Public Investment Corporation (PIC) also owns a $17.2 \%$ stake in Naspers (Parker, 2014, p. 15). The PICs investment exhibits a conflict of interest, given it has invested, along with the Government Employment Pension Fund (GEPF) in numerous media houses, both of which are linked to government capital (Parker, 2014, p. 15). In 2013 Naspers celebrated its $19^{\text {th }}$ year listed on the JSE (Smith, 2013, Internet). If you invested R100 000 in the consortium 19 years ago your shares would be valued at R26 million (Smith, 2013, Internet). In
2015, one share in the media empire would be worth R2 022.92 (van Zyl, 2015, Internet).

2.2. The Caxton/CTP Group mainly publishes local and community publications and still maintains a majority of white ownership, scoring 0 out of 100 points for black ownership and only 2.46 out of 15 for employment equity (Moodie, 2014 , p. 22). This is negatively perceived in terms of South African legislation and the diversification of the media industry. Caxton was taken under new ownership in 1980 by Terry Moolman and Noel Coburn who took over ownership of the Perskor (Afrikaanse Pers Korporasie) media company, who like Naspers, were largely an Afrikaans publishing company with close ties to the Apartheid government. Caxton underwent transformation in 1998 and merged with a Cape Town Printer to form Caxton Publishers and Printers. Caxton largely publishes community newspapers along with the Citizen its only national publication and 13 major magazine titles part of its Penrose stable. Caxton is also a large printer, publisher and packager of books and other commercial publications and magazines (Caxton website, 2015, Internet).

In August 2014 Caxton announced a decline in gross profits from R502.8 million to R435.9 million. This recorded a $13.3 \%$ loss to the media house and a $19.8 \%$ loss per share of the company (Cairns, 2014, Internet). However, capital was still stable with Caxton acquiring $51 \%$ of Mega Digital, a Cape Town printer, a $100 \%$ buyout of Habari Media and a further 70\% stake in Ramsey Media which produces 3 national titles. Caxton declared a revenue of R3 273 billion with investment opportunities to help curb losses over the year (Cairns, 2014, Internet). Caxton attributed its losses to a weakening Rand and a difficult trading environment due to increased costs (Cairns, 2014, Internet). Caxton is listed on the JSE (as CAT) and shares are trading at R1 976 per share (Financial Times, 2015, Internet). Caxton like Naspers has a long established history in the South African media industry and has had a stable ownership for the last 35 years.

2.3. The Independent Media Group (IMG) in 1995 expanded its market share when it gained a 35\% stake in the Argus Group belonging to Anglo American and the mining industry during South Africa's colonization period, thus shaping its current spectrum to become the largest publisher of English titles today (Oosthuizen, 2001, p. 139). The IMG was sold post1994, to change its dialogue and readership, to an Irish owned consortium, owned by Tony O'Reilly, which renamed the group to Independent News and Media Group (INMG). Under its Irish based ownership the group had been under criticism for repatriating profits 
instead of reinvesting them, thus leading to a financial crisis of the media group. In 2013 it was renamed to the Independent Media Group (IMG) under its new ownership of Sekunjalo (IMG website, 2014, Internet).

IMG was bought out in 2013 for R2 billion (Rumney, 2013, p. 57). The buy-out of the IMG involved three main named investors, the PIC, a state owned entity, would own 25\% (R500 million), while Sekunjalo whose list of owners and investors has close ties to the ANC - will own a further 55\%. The remaining ownership will be bought by the Chinese-African Development Fund and the Chinese International Television Corporation (Parker, 2014, p. 14). The deal was questioned by the Competition Commission and other regulatory bodies for several reasons.

Firstly, how the money was acquired for the deal; Sekunjalo went into a loan agreement with the Chinese state owned entities, further asking how much did Chinese owners actually contribute to the deal. Secondly, the Chinese stake is kept in Mauritius, for tax purposes, questioning the transparency of the deal. Thirdly, the PIC also owns stake in the TMG and Media24, raising concerns over fair competition practices in that an investor may want to high returns in all investment and engage in price fixing to ensure profitability (Parker, 2014, p. 15). These questionable activities leading up to the deal of Sekunjalo buying IMG raised concerns over the continued independence and transparency of the group, given the amount of state owned investment, including foreign state ownership, in the deal. In August 2013 Sekunjalo successfully gained ownership of IMG - the competition commission approved the deal and stated that the "Chinese will have control over Independent" (Mckune, 2013, Internet).

Sekunjalo Investment Holdings has recently been renamed to African Equity Empowerment Investments Limited (AEEI and listed on the JSE as AEE) (Smith, 2015, Internet). The rebranding was for the purpose of highlighting its objectives as a company and one of South Africa's largest BEE contributors (Smith, 2015, Internet). The shareholder make-up of AEEI is; a Chinese investment consortium named Intracom Investment Holdings, trading under Newco who owns a $20 \%$ stake; the PIC owns a majority of $55 \%$ and the GEPF owning a 25\% stake (Parker, 2014, p. 15; \& Harber, 2013, Internet). The GEPF is Africa's largest pension fund, with assets worth over R1 trillion (GEPF website, 2015, Internet). GEPFs stake in AEEI is worth around R500 million (Gunnion, 2013, Internet). By 2014 year end the IMG announced its net profit of R108 million from R59 million in 2013 - an 84\% increase under new ownership and investment (M\&G, 2014, Internet).
The new ownership of the IMG has both positives and negative outcomes; negatives are surrounding the state loan agreement for the buy-out of the group and how the group intends on retaining its independence and South African appeal given its lucrative ownership (Rumney, 2015, p. 68). It may repeat the mistakes of its previous owned Irish entity and cause the IMG to run at a loss. In a positive perspective, the BEE status of AEEI complies with the legal repertoire of South Africa and there is thus more room for a diverse ownership and content. The new ownership may also mean that AEEI will open up the IMG for more investment and ownership opportunities. The IMG has yet to prove its long term success given its new ownership, yet has remained stable over the last two years of its ownership. Analysts have also queried how profitable FDI into the IMG would be given that majority of its shareholders are linked to government financial assets and a retracement of PIC and the GEPF from AEEI would amount to a financial crisis of the consortium affecting the IMG (Gunnion, 2013, Internet).

2.4. The Times Media Group (TMG) was founded in 1906 under the name of South African Associated Newspapers (SAAN). The group was founded by Sir Abe Bailey, a wealthy mining businessman, who founded the Rand Daily Mail. In the 1970's the group faced a financial crisis and the National Party attempted to buy out the media group. A rescue operation consisting of the mining company AngloAmerican kept them out of government's hands yet saw a major restructuring of ownership leaving the Argus group with only a $40 \%$ ownership and the Anglo-American mining group with a majority ownership. It was only in 1987 that the group was again restructured and renamed to Times Media Ltd (TML). By 1996 Johnnic Communications, owned by the Anglo-American group owned a $46 \%$ stake in the TML. In 1998 a black empowerment group, National Empowerment Consortium (NEC), took over Johnnic. The NEC extended its media interests and in 2000 it sold $50 \%$ of its two largest publications to a UK based business (The Business Day and the Financial Mail). The company only represented $1 \%$ of the total market share of the media industry (Oosthuizen, 2001, p. 143).

In 2013 TMG was sold to Andrew Bonamours, owner of Blackstar Equity (Moodie, 2014, p. 22). TMG again restructured itself after its sale to recover a R1.1 billion debt and it regained full control over Business Day, Financial Mail and also the African Broadcasting Channel to lift profits of the business (Gunnion, 2013, Internet). Restructuring of TMG reduced debt from R1.1 billion to R698 million in one year (TMG Annual 
Report, 2013, p. 2). TMG attributed its growth to a $32.3 \%$ stake in a Ghana Multimedia consortium, as well as a 49\% stake in Kenya's Radio Africa Group. Stakeholders in the TMG include; The Coronation Fund at $15.5 \%$; PIC at $19.2 \%$ stake (Parker, 2014, p. 15) and initially Caxton at $10.4 \%$ (Gunnion, 2013, Internet). However, Caxton in 2014 sold R100 million worth of its Times Media shares, significantly reducing Times Media shareholding to R9.5 million from R14.7 million. Blackstar spent a further R124.5 million pushing its stake over $20 \%$ in the company (Ndzamela, 2014, Internet).

2.5. TNA Media is the newest independently owned news title in South Africa which was launched in 2010. TNA Media owns New Age and forms part of Infinity Media Ltd which owns ANN7, a news broadcaster (Parker, 2014, p. 13). Both are controlled by India's Gupta family. Shares are split accordingly: $35 \%$ in Oakbay, a Gupta investment vehicle; Essel Media holds further 35\%; BBBEE Mabengela Investments - whose biggest shareholder is the president's son Duduzane Zuma own a $45 \%$ stake and a further $25 \%$ stake is owned by Rajesh Kumar Gupta. 9\% is reserved for staff and management (Parker, 2014, p. 13). The development of media owned by the Gupta's has been termed as a government-friendly media market (SoN, 2014, p. 6; \& de Wet, 2013, Internet). Their ownership is largely reflective of political influence and has yet to be reviewed in terms of financial indicators. Yet, given its backing by Oakbay and Essel Media, investment cannot yet be disregarded, yet caution is advised until the publications regulated financial figures can be released.

2.6. The Mail and Guardian (M\&G) is the most successful independently owned title in the country. The M\&G was launched in 1985 by a group of journalists who had been retrenched due to publication closures. The publication has also taken the trajectory of a watchdog of the state (M\&G website, 2015). The publication has an average circulation of more than 50000 per week. The ownership of the company is the only one which has no influence of any state entity or questionable shareholders. It is $77.69 \%$ owned by Trevor Ncube, a Zimbabwean entrepreneur; a 10\% dividend each belongs to the M\&G Staff Share and the Media Development Investment Fund; and the remaining $2.31 \%$ belongs to minority shareholders (M\&G website, 2015, Internet). According the SoN (2014, p. 19) the M\&G's BBBEE compliance is underperforming yet fairs better than its giant competitors with an almost even split between black and white in ownership and editorial positions.

\section{Macro risks related to FDI in South Africa's news media industry}

Macro specific risks refer to those risks which affect the business because of risks which occur on a country scale. The Institute for Risk Management South Africa (IRMSA) (2015, p. 11) identified ten macro risks for businesses to be aware of; 1) increased corruption; 2) increased unemployment; 3) shortfall of critical infrastructure; 4) political and social instability; 5) escalated organized crime; 6) cyber-attacks; 7) financial mechanism; 8) income disparity; 9) urbanization; and 10) data fraud (IRMSA, 2015, p.11). Drawing on these ten indicators we may establish two areas of concern to the media industry; financial indicators (economy and employment in the media industry); and political indicators (legislation and government policy in the media industry).

3.1. Financial indicators. The media industry must be profitable to exist. South Africa's economic situation continues to decline with the current exchange rates according to the South African Reserve Bank (SARB, 2015 , Internet) at $\mathrm{R} / \$<12.9010 ; \mathrm{R} / £<20.2771$; and $\mathrm{R} / €<14.5181$ (21/08/2015). The rand dropped $0.9 \%$ to R13.0030 per dollar on 20 August 2015, which extended losses this year to $11 \%$. This recorded a 14year lowering for the country's exchange rate (Potelwa, 2015, Internet). Stats SA (Statistics SA, 2014, Internet) also reported by the fourth quarter of 2014 the GPD had grown by $1.5 \%$, a decline from a $2.2 \%$ growth in 2013. Low growth rates impact an already struggling media industry because the market which the commercial sector appeals to is the working class. Circulation rates of publication have declined slightly which also presents a challenge to investors and the media industry to avoid large growth losses (Louw, 2014, Internet). SoN (2014, p. 1) also recorded that between 2013 and 2014, there were 596 retrenchments within the news media industry - this depicts a negative picture of financial indicators for FDI.

The Audit Bureau of Circulations (ABC) (ABC, 2014, Internet) released its fourth quarter results for 2014 showing a decrease in newspaper sales; newspaper circulation was down by 66000 copies and magazines down by 560000 copies. However, $\mathrm{ABC}$ did note there was growth in specific titles such as the Saturday Dispatch; circulation of 19561 to 21972 (ABC, 2014, Internet). The National Association of Broadcasters (NAB) (NAB, 2015, p. 10) however shows a much more prospective opportunity for growth within the broadcasting industry of South Africa. With substantial growth in commercial television reach (Multichoice, MNet) from 14.6 million in 2013 to 16 million in 2014 and E.TV (Free-to-air channel) growing from 24.7 million in 2013 to 25.2 million in 2014. 
It is critical to understand the implications of these figures as being; broadcasting in South Africa reaches more viewers because of poverty and illiteracy rates, as well as a wider availability of free television; the commercial media sector appeals to those who form part of the economic mainstream, middle working class consumers are able to afford subscription fees for media consumption (Moyo \& Chuma, 2010, p. 40); and there is a need to acknowledge that there is an increasing ability to receive information via the internet for free which decreases the market of paid media (The Media Online, 2014, Internet). Having discussed these implications, potential investors should be aware of the challenges facing the South African economy. Economic issues are broad and there are a multitude of areas which negatively affect the media industry. For example the current electricity supply crisis even has a negative impact on the media industry considering it relies on electronic technology such as computers, printing machinery and internet connectivity to operate on a daily basis. Without which profits will be negatively affected and growth will slow down.

3.2. Political and legal indicators. There are two primary legislative concerns investors should consider when investing in the news media industry of South Africa. Firstly it is critical to understand how political and legal factors can impose serious threats to the industry. Fourie (2001, p. 121) and Duncan (2014, p. 169) use the concept of the political economy in relation to the media industry arguing that political economy relates to political and social interactions. However, it is theoretically much more important for the media because theories of the political economy argue that the economy is the foundation of all social institutions, including the media, thus economic and political control determine the output of the media. Thus, Fourie (2001, p. 122) and Duncan (2014, p. 169) are arguing that from a political economy perspective, the media and how media markets operate, is part of a capitalist economic system which is linked to the political system of a country and underlying economic interests of media owners. This highlights the link between politics, the economy and media owners in the functioning and success of the industry as a whole.

The first concern for investment is legislative turnover which promotes nationalist ideals and demotes free market growth in the private business sector. The paper has discussed the three controversial bills which government promoted. The POIB was adopted by parliament in 2013 but not signed by the president, who asked for further changes. These changes however were not adequate for opposition parties and protest organizations such as Right 2 Know (R2K). The bill presents clauses prohibiting the free flow of information, particularly that which is classified as state sensitive information (SoN, 2013, p. 16). It also does not protect journalists and whistle-blowers from the law. Protest against the POIB has been substantial and kept the bill from implementation for the last five years, however it still could be realized as a major step away from the democratic position of the media in South Africa. The MAT has fallen into the background of government's agenda for the timebeing with no mention of its implementation this year (SoN, 2014, p. 21). However in April this year the minister of communications, Faith Muthambi, did call for a revised inquiry into the regulation of the media and ANC spokesman, Zizi Kodwa, did confirm the party would continue to call for the MAT which would implement a state regulatory system (City Press, 2015, Internet).

These controversial bills highlight a step away from press freedom in South Africa. For potential investors the ability of South Africa to be seen as a stable democratic country is critical for promoting investment and instability in legislation presents a high risk for FDI. However, the Constitution of the country and opposition groups are expected to keep these bills from implementation, yet thus far no real success has been achieved of cancelling these bills completely and potential investors are urged to consider the negative impact if such implementations are realized.

The second concern is that media ownership should be free from any political interference. Media businesses should operate independently from government to avoid reverting to mouthpieces of the state as in the Apartheid era. Within the above discussion of the various media houses it should be highlighted that there is considerable indirect political influence of shareholders and owners; AEEI who owns IMG has close relations with the ANC ruling government and during their buy-out of the group they equated the sale as a "gift" to former president Nelson Mandela (Bdlive, 2013b, Internet). The PIC is also a cause for concern, holding shares in the IMG, TMG and Naspers. This conflict of interest is concerning for the competition commission who must ensure that the media industry is free from any ownership which could implement price fixing and anti-competition (Bdlive, 2013b, Internet). The newest publication owned by TNA media is also problematic concern given that its ownership make up envisions for a government friendly business (SoN, 2014, p. 6). However present government's influence is indirect and there has been no direct control by government in ownership in the news media industry. 


\section{Micro risks of FDI in South Africa's news media industry}

Micro risks are considered to be those risks which originate and relate directly to the industry concerned. The micro risk factors of FDI into the South African news media industry can be explained using three primary indicators; concentration of media ownership; re-structuring of ownership; and a transparency of ownership. These indicators will be explained and contextualized in order to understand their importance to FDI.

4.1. Concentration of ownership. Concentration of ownership refers to the majority of the news media industry being owned by a minority of people (Fourie, 2001, p. 112). South Africa's news media industry is largely owned by four media houses; Nasionele Pers (Naspers-Media24-Mutlichoice); Caxton/CTP publishers; Independent Media; and Times Media Group (Moodie, 2014, p. 22). According to Oosthuizen (2001, p. 132) and Malila (2014, p. 15) concentration of the media industry negatively effects economic variables such as competition and pricing because fewer owners mean that they have control over these economic factors and can fix them to receive the highest profits available.

However in terms of risk assessment it is important to consider the arguments of Daniels (2012, p. 43), Angelopulo \& Potgieter (2013, p. 3) and the SoN (2013, p. 2) who state that even though there may be few owners' variation of content and pricing within them is broad. Son (2013, p. 2) highlights the availability of publications and how media owners target different markets within the public so pricefixing is not evident. Daniels (2012, p. 44) states that Media24 publishes the Daily Sun which is South Africa's biggest selling daily paper (circulation of 374400 ). It is an English tabloid style publication and targets low wage working class citizens. Media24 also publisher Rapport, an Afrikaans weekly which provides news and information to Afrikaans working class citizens. Caxton (2015, Internet) also publishes community newspapers which are free to the public while still publishing the Citizen, its daily national paper and 13 lifestyle magazines.

These examples highlight the different target audiences of media house with the wide availability of market share. Thus while concentration can become problematic as Oosthuizen (2001, p. 132) and Malila (2014, p. 15) discuss, in terms of the South African news media industry it is unlikely that concentration will be a risk factor for shareholders. The big four media houses sustain high profits and stability of their markets; Caxton has a market capitalization of R8 Billion and Naspers has around R0.752 Trillion. They are often also more transparent in shareholder make-up and ownership because they are publicly listed on the JSE, besides the IMG (Rumney, 2015, p. 68).

4.2. Restructuring of ownership. Restructuring and new ownership refer to the transformation of the news media industry, as have been seen in the past two years in two of the media houses discussed above; TMG and IMG. These ownership changes rose concerns with independent regulator, SANEF, as to the public knowledge of whom shareholders are, what shareholder agreements and beneficiaries exist; and the increased political involvement and executive overreach in the respective companies (Rumney, 2013, p. 57). Business restructuring is often done in order to recover debts as with the IMG and thus there are two possible outcomes for shareholders; market shares will open and be available to an array of new owners and profitability can increase, as in the case of TMG. Restructuring of TMG reduced debt from R1.1 billion to R698 million in one year (TMG Annual Report, 2013, p. 2). Restructuring however could also mean that majority of shareholders are consolidated by one owner as in the case of IMG where AEEI holdings own a 55\% stake (Parker, 2014, p. 14).

Restructuring is not unique to cases where media houses are bought out and sold off but also refers to internal restructuring such as retrenchments and closing of publications in order to sustain profitability. SoN (2013, p. 3) state that between 2012-2013 the news media industry shed around 500 jobs within its newsrooms because of the continuing downturn of the economy. Media24 shed 44 positions and $10 \%$ of its editorial staff in its Afrikaans newsrooms and 53 positions from its English newsrooms. TMG shed 18 senior staff members and before AEEI bought out IMG 3000 positions where lost within the group. These figures highlight the difficulty of the news media industry to maintain profitability given the state of the South African economy.

4.3. Transparency of ownership. Transparency refers to the availability, to the public, of ownership and shareholder make-up. Transparency is problematic in that it can present a conflict of interest as in the case of IMG and TNA whose ownership make up lists of Chinese state ownership and individuals with close or actual family relations to the government of South Africa (Harber, 2013, Internet). The influence of government and the state presents a risk for shareholders in that it is not representative of a democratic state. Privately listed media houses do not need to disclose their shareholder and ownership make up and are there not subjected to public scrutiny, as the PIC has been. The PIC holds a $17.2 \%$ stake in Naspers (Parker, 2014, p. 15), a 25\% stake in IMG (Harber, 2013, Internet) and a $19.2 \%$ stake in TMG (Gunnion, 2013, Internet). The PIC's investment in multiple 
media house is a concern for investment because it presents a risk of anti-competition practices existing in the media industry and also questions the intention of the PIC and the protection of confidentiality of these media businesses (Parker, 2014, p. 15).

Rumney (2015, p. 68) however argues that no stakeholders possess enough control of any media house to effectively control prices and content. The PIC cannot engage in price-fixing and anti-competition to benefit its own profitability with less than a $26 \%$ stake in either of these media houses. However, the PIC may present a risk in the case of IMG; it holds a $25 \%$ stake in the media house and also holds a $55 \%$ stake in AEEI, who is the majority owner of IMG (Parker, 2014, p. 15; \& Harber, 2013, Internet). Daniels (2012, p. 49) emphasizes the importance of ownership and shareholder make up remaining autonomous from the editorial and Fourth Estate functions of the media. Shareholders must remain focused on returns of their investment and allow for the news media industry to remain independent of any executive overreach. Without this relationship between shareholders, owners and editorial independence the risk of the media industry moving away from its democratic position of ownership is high.

\section{Conclusion: forecast and recommendations}

The glass full scenario. Government has, since the early stages of democracy in South Africa expressed political will in transforming the news media landscape. They have consistently criticized media for concentration and a lack of a developmental agenda (Malila, 2014, p. 15). Rumney (2015, p. 68) however argues that there is no single dominant stakeholder present which can exercise complete control over any media house. In addition to this, the stock market regulates all media houses which are publicly listed, thus providing transparency within the industry (beside the case of IMG and TNA). Burger (2007, p. 100) adds that the constitution is enshrined with independence from commercial or political interference. Thus we have seen, since 2007 with the MAT, a continued push from government to censor media in some way or another but their success has been limited to indirect influence over some owners and shareholders. Even the New Age has shown little success in leading a developmental framework (Rumney, 2015, p. 68).

This means that the most likely trajectory of the news media industry is that it will see further growth and diversification of ownership and shareholders in the years to come which will promote and strengthen legislative acts such as BBBEE. There will be a continued effort from the public to, at most, prevent legislation turnover and at least, keep stalling implementation until regulations are revised so that they cannot threaten the Fourth Estate objectives and independence of the media industry. The current concerns for investment in the news media industry largely relate to an ongoing economic crisis in South Africa which has led to a continuing decline of circulation. Since 2008 circulation has decreased at $5.5 \%$ annually (SoN, 2013, p. 2).

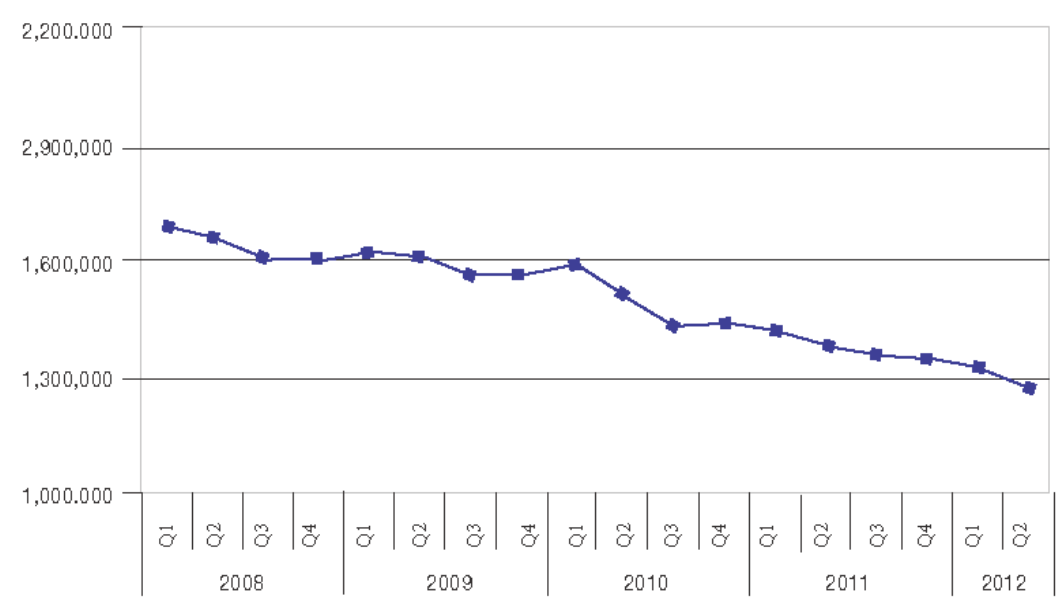

Fig. 1. The four year trend analysis shows a decline of daily newspapers

Source: SoN, 2013, p. 2.

However the trend of news media to make use of technological innovations such as online publications shows promise of new and growing market which will ensure continued success of the industry (SoN, 2014, p. 29). The current landscape for investment in the private news media industry holds however a mixture of positive and negative factors but overall the environment is stable and there is ample opportunity to gain stake in the news media industry. The "glass for investment" is thus full, of not one but a multitude of different factors and opportunities to consider, along with its risks. The media landscape is definitely large enough to accommodate more foreign and diverse ownership, 
and it is a positive move which welcomes foreign currency into the country (Parker, 2014, p. 15).

The glass half empty scenario. This scenario considers a negative trajectory of the industry and an unstable investment environment. In the least likely event that the industry will be exhausted from a struggling economy, continued retrenchments and a lack of investment in the sector. However besides economic factors Parker (2014, p. 12) argues that the biggest concern for the news media industry is that "he who pays the piper, calls the tune". This means that media owners will use their positions to undermine editorial independence of the media. Parker (2014, p. 12) further argues that the industry owners can be categorized into two distinct types; one which is government-linked; and the other in which powerful corporate owners are focused on profits and not the Fourth Estate agenda of the press. Rumney (2015, p. 68) argues above that it is impossible to simplity media ownership to this extent and the array of owners and stakeholders prevent such a control.

It is however not impossible that the news media industry could steadily become more controlled by its owners and that government influence can become more direct. Legislation may turn to favor a more state controlled press in which case the media would revert to its pre-1994 authoritarian status. SoN $(2014$, p. 12) cite an example of Iqbal Surve, who was the head of AEEI (then Sekunjalo) in 2013 suspending the editor Alide Dasnois of the Cape Times (one of the IMG publications) after running a story on the Public Protectors report implicating Sekunjalo in an improper tender from government. This is a clear example of executive controls ability to undermine the editorial independence of its publications. However this type of situation has not been common and has been met with fierce criticism independent regulators and public activist groups such as R2K. Rumney (2013, p. 57) states and example of when SANEF expressed concern over the lack of information provided by Sekunjalo over whom its shareholders were and how its funding was intended. It is unlikely though, given the variation of shareholders in media companies that these situations would become common place in the South African news media landscape.

The glass half full scenario. This scenario depicts the ideal and most suitable environment for investment and growth within the media industry. Ideally the news media market should encompass an environment which consists of free enterprise, democratic ownership, fair competition and content disseminating from a variety of sources (Oosthuizen, 2001, p. 132). There should not be any political interference, even indirect situations, which have been seen the South African media industry. It is also critical that government does not initiate policies which promote control and censorship of the press.

This scenario would also see more transparency of ownership and shareholders of media houses. Rumney (2015, p. 68) states that only 3 of the big four are publicly listed on the JSE; Naspers (Media24), TMG and Caxton. The IMG is no longer listed on the JSE and shareholder information is only available through its owner AEEI. TNA has also rejected to have its publication, New Age, audited by the Audit Bureau of Circulations (ABC). In order for investment to thrive it is necessary for the media industry to exhibit transparency. However JSE listing is not the only means whereby transparency can be found, companies also produce annual reports and disclose this information within them. Parker (2014, p. 13) for instance states the shareholder makes of the TNA group as Oakbay Investments, Essel Media, Mabengela Investments and staff and management shares. This shows that the news media industry is not necessarily hiding its ownership and shareholders from the public.

However ideally investment would be more stable where no initiatives of censorship and legislative turnover exist and all media owners publicly disclose ownership and shareholder information for the purpose of ensuring fair competition and free enterprise within the market (Parker, 2014, p. 15). Given that government has been pursuing legislative initiatives which harm the independence of the news media industry since 2007, it is highly unlikely they would abandon all their initiatives in the 'spirit' of independence and freedom. It is also unlikely that media owners would, without pressure from regulatory bodies, disclose all information for the sole purpose of embracing a transparent media landscape. Thus there is still work to be done in order to realise this ideal media environment.

\section{References}

1. ABC. (2014). Audit Bureau of Circulations Website. Available at: http://www.abc.org.za/Notices.aspx/Details/42.

2. Angelopulo, G. \& Potgieter, P. (2013). The economic specification of media ownership in South Africa, South African Journal for Communication Theory and Research, 39 (1), pp. 1-19.

3. Bdlive. (2013a). Caxton buys out Habari Media. Business Day Live, 10 December 2013. Available at: http://www.bdlive.co.za/business/media/2013/12/10/caxton-buys-habari-media.

4. Bdlive. (2013b). Why the secrecy of Independent. Business Day Live, 26 May 2013. Available at: http://www.bdlive.co.za/opinion/columnists/2013/05/26/last-word-why-the-secrecy-over-independent. 
5. Burger, G. (2007). Media Legislation in Africa: A Comparative Legal Survey, Rhodes University School of Journalism and Media Studies, September 2007. Available at: http://www.unesco.org/new/en/communication-andinformation/resources/publications-and-communication-materials/publications/full-list/media-legislation-in-africa-acomparative-legal-survey/.

6. Cairns, P. (2014). Caxton reports lower profits. Moneyweb Website, 26 August 2014. Available at: http://www.moneyweb.co.za/uncategorized/caxton-reports-lower-profits/.

7. Caxton Website. (2015). Caxton and CTP Publishers Website. Available at: http://www.ctpprinters.co.za/company-info/history/.

8. City Press. (2015). Government renews call for state-controlled media regulation. City Press, 26 April 2015. Available at: http://businesstech.co.za/news/media/85992/government-renews-call-for-state-controlled-media-regulation/.

9. Daniels, G. (2012). Fight for democracy: The ANC and the media in South Africa. Johannesburg: Wits University Press.

10. De Wet, P. (2013). South Africa's (political) media landscape. Mail \& Guardian Online, 30 August 2013. Available at: http://mg.co.za/article/2013-08-30-00-south-africas-political-media-landscape.

11. Duncan, J. (2014). A political economy of press self-regulation: the case of South Africa, Media Culture and society, 36 (2), pp. 167-182.

12. Fourie, P.J. (2001). Media Studies, Volume 1: Institutions, Theories and Issues. Cape Town: Juta Education.

13. Financial Times. (2015). Caxton and CTP Publishers and Printers Ltd. Financial Times Online, 18 September 2015. Available at: http://markets.ft.com/research/Markets/Tearsheets/Business-profile?s=CAT:JNB.

14. GEPF website. (2015) Government Employee Pension Fund Website. Available at: http://www.gepf.gov.za/index.php/about_us/article/who-is-gepf.

15. Gunnion, S. (2013). Media ownership comes home to roost. Business Day Live, 07 June 2013. Available at: http://bdlive.co.za/business/media/2013/06/07/media-ownership-omes-home-to-roost.

16. Harber, A. (2013). Chinese 'soft diplomacy' enters South Africa's media space. Business Day Live, 27 June 2013. Available at: http://www.bdlive.co.za/opinion/columnists/2013/06/27/chinese-soft-diplomacy-enters-south-africasmedia-space.

17. IMG website. Independent Media Group website. Available at: http://www.independentmedia.co.za/en/ourcompany/about-us/.

18. IRMSA. (2015). IRMSA Risk Report: South Africa Risks 2015. The Institute of Risk Management South Africa, first edition. Available at: http://www.irmsa.org.za/?page=IRMSARiskReport.

19. Letsebe, L. (2012). The Protection of State Information Bill: Is the 'liberator' crossing the floor? (De Rebus). IHR website, 2012. Available at: http://www.lhr.org.za/news/2012/protection-state-information-bill-\%E2\%80\%98 liberator\%E2\%80\%99-crossing-floor-de-rebus.

20. Louw, R. (2014). The evolution of South African media over 20 years. The Media Online, 16 April 2014. Available at: http://themediaonline.co.za/2014/04/the-evolution-of-african-media-over-20-years-south-africa/.

21. M\&G website. (2015). Mail \& Guardian Website. Available at: http://mg.co.za/page/about-us/.

22. M\&G. (2014). Iqbal Surve resigns from Sekunjalo. Mail and Guardian Website, 06 November 2014. Available at: http://mg.co.za/article/2014-11-06-iqba-surve-resigns-from-sekunjalo.

23. Malila, V. (2014). Tracing the ANC's criticism of the South African Media, Rhodes Journalism Review, August 2014, pp. 13-15. Available at: http://www.rjr.ru.ac.za/no33.html.

24. McKune, C. (2013). The Independent Media Group deal's unanswered questions. Mail \& Guardian Online, 30 August 2013. Available at: http://mg.co.za/article/2013-08-30-00-the-independent-media-group-deals-unanswered-questions/.

25. Moodie, G. (2014). The slippery question of media ownership, Rhodes Journalism Review, August 2014, pp. 21-23. Available at: http://www.rjr.ru.ac.za/no33.html.

26. Moyo, D. \& Chuma, W. (2010). Media policy in a changing Southern Africa: critical reflections on media reforms in the global age. Pretoria: UNISA Press.

27. NAB. (2015). State of the Broadcasting Industry Report 2014. National Association of Broadcasters, November 2014. Available at: http://www.nab.org.za/uploads/files/NAB_State_of_the_Broadcasting_Industry_Report_2014__November_2014_\%28Final\%29.pdf.

28. Naspers Website. (2015). Naspers website. Available at: http://www.naspers.com/our-history.html.

29. Ndzamela. (2013). Blackstar increases stake in Times Media. Business Day Live, 01 October 2013. Available at: http://www.bdlive.co.za/business/media/2013/10/01/blackstar-increases-stake-in-times-media.

30. Oosthuizen, L.M. (2014). Media Ethics in the South African Context: An Introduction and overview, Second Edition. Cape Town: Juta \& Company Ltd.

31. Oosthuizen, L.M. (2001). Media Ownership and Control. In Media Studies Volume 1: Institutions, Theories and Issues. Edited by Fourie, P.J. Cape Town: Juta \& Company Ltd.

32. Parker, M. (2014). Media: He who pays the piper, calls the tune. New African, September 2014, 542, pp. 12-15. Available at: http://0-web.b.ebscohost.com.ujlink.uj.ac.za/ehost/detail/detail?vid=3\&sid=726b4246-dff5-45cda345-17977d101b58\%40sessionmgr113\&hid=101\&bdata=JnNpdGU9ZWhvc3QtbG12ZSZzY29wZT1zaXR1.

33. Potelwa, X. (2015). Rand breaches R13/\$ for the first time in 14 years. News 24 Website, 20 August 2015. Available at: http://www.fin24.com/Economy/Rocky-road-for-rand-with-R13-breach-expected-soon-20150820.

34. Reporters without Borders. (2015). 2015 World Press Freedom Index. Available at: http://index.rsf.org/\#!/indexdetails/ZAF. 
35. Rumney, R. (2015). 20 years of changes in media ownership. Rhodes Journalism Review, August 2015 , pp. 66-69. Available at: http://www.rjr.ru.ac.za/no33.html.

36. Rumney, R. (2013). Media ownership and transparency. Rhodes Journalism Review, August 2013, pp. 57-58. Available at: http://www.rjr.ru.ac.za/no33.html.

37. SARB. (2015). South African Reserve Bank Website. Available at: https://www.resbank.co.za/Pages/default.aspx.

38. Stats SA. (2015). Statistics South Africa Website. Available at: http://www.statssa.gov.za/?p=4184.

39. Smith, C. (2015a). How Naspers made millionaires. News24 Website, 13 April 2015. Available at: http://www.fin24.com/Tech/Companies/How-Naspers-made-millionaires-20150413.

40. Smith, C. (2015b). Sekunjalo rebrands to avoid confusion. News24 Website, 16 April 2015. Available at: http://www.fin24.com/Companies/Financial-Services/Sekunjalo-rebrands-to-avoid-confusion-20150416.

41. Smith, C. (2013). R100 000 in Naspers over 19 years' worth R26m. News24 Website, 13 September 2013. Available at: http://www.fin24.com/Companies/ICT/R100-000-in-Naspers-over-19-years-worth-R26m-20130913.

42. SoN. (2014). State of the Newsroom 2014 South Africa: Disruptions Accelerated. Wits Journalism, 2014. Available at: http://www.journalism.co.za/wp-content/uploads/2014/10/State-of-the-newsroom-2014.pdf.

43. SoN. (2013). State of the Newsroom 2013 South Africa Disruptions and transitions. Wits Journalism, 2014. Available at: http://www.journalism.co.za/wp-content/uploads/2014/03/State_of_the_newroom_20131.pdf.

44. Thloloe, J. (2012). The South African Regulatory Regime in Print, Broadcasting and Online. In Media Landscape 2012. Edited by Seery, U. Available at: http://www.gcis.gov.za/sites/www.gcis.gov.za/files/docs/resourcecentre/Foreword.pdf.

45. Van Zyl, G. (2015). Naspers bursts through R2 000-mark. News24 Website, 13 April 2015. Available at: http://www.fin24.com/Tech/Companies/Naspers-bursts-through-R2-000-mark-20150413.

46. TMG Annual Report. (2013). TMG Annual Integrated Report 2013. Times Media Website, September 2013. Available at: http://www.timesmedia.co.za/wp-content/uploads/2013/09/TMG-annual-report.pdf.

47. Vilakati, S. \& Mavindidze, Z.N. (2014). A comparative study of legislation and regulations establishing ownership ceilings, audience size, market share and geographic markets in the South African print media sector, Freedom of Expression Institute, 1 (2), pp. 1-33.

48. Visser, A. (2014). Media24 may face R20M competition penalty for goldfields pricing strategy. Business Day Live, 14 November 2014. Available at: http://www.bdlive.co.za/business/media/2014/11/14/media24-may-facer20m-competition-penalty-for-goldfields-pricing-strategy. 